\title{
ANALISIS PERMASALAHAN PELAKSANAAN PRAKTIK KERJA LAPANGANMAHASISWA PROGRAM STUDI D-3 ADMINISTRASI BISNIS JURUSAN ADMINISTRASI NIAGA POLITEKNIK NEGERI JAKARTA
}

\author{
Ni Made Widhi Sugianingsih ${ }^{\text {1)}}$, Narulita Syarweni ${ }^{2)}$ dan Wahyudi Utomo ${ }^{3)}$ \\ 1,2,3 Jurusan Teknik Mesin, Politeknik Negeri Jakarta \\ E-mail: 므m.widhi@bisnis.pnj.ac.id , ${ }^{2}$ narulita.syarweni@bisnis.pnj.ac.id, ${ }^{3}$ Wahyudi.utomo@bisnis.pnj.ac.id
}

\begin{abstract}
Abstrak
Praktek Kerja Lapangan (PKL) merupakan salah satu bentuk implementasi secara sistematis dari program pendidikan yang ada di program Studi Administrasi Bisnis. Mahasiswa dapat mengaplikasikan dan mempraktekkan secara langsung teori dan praktik yang sudah diperoleh di perkuliahan, dengan kegiatan kerja secara langsung di dunia kerja, baik itu di perusahaan swasta, perusahaan BUMN, ataupun di Instansi Pemerintah. Evaluasi terhadap pelaksanaan program praktik kerja lapangan ini perlu terus dilakukan dalam upaya mengatasi permasalahan yang dihadapi dan upaya perbaikan serta penyempurnaan. Penelitian ini bertujuan untuk memperoleh gambaran yang lengkap dan mengevaluasi mengenai permasalahan yang dialami mahasiswa dalam melaksanakan praktik kerja lapangan, sehingga nantinya dapat dilakukan perbaikan dan penyempurnaan. Di samping itu pula mengevaluasi buku pedoman praktik kerja lapangan dan penulisan laporan tugas akhir agar dapat direvisi. Analisis data dilakukan dengan pendekatan kualitatif deskriptif, yaitu dengan mengeksplorasi program kegiatan praktik kerja lapangan dengan tujuan memperoleh deskripsi tentang permasalahan, penggalian informasi yang beragam melalui kuesioner, wawancara dengan mahasiswa, dosen pembimbing, serta struktural jurusan, sehingga diperoleh upaya untuk mengatasi permasalahan yang ada. Sebagai responden dalam penelitian ini adalah seluruh mahasiswa dan mahasiswi semester 6 yang sudah melaksanakan praktik kerja lapangan pada tahun akademik 2017/2018. Adapun hasil dari penelitian ini adalah memang ditemukan permasalahan yang dialami oleh mahasiswa, seperti pada saat pengajuan PKL terkait dengan penentuan tempat PKL, bidang peminatan, dan kendala administrasi. Pada saat pelaksanaan PKL terkait dengan jangka waktu PKL, kesesuaian bidang pekerjaan dan penilaian. Setelah pelaksanaan PKL selesai, terkait dengan kendala komunikasi dan kurangnya pemahaman pada penggunaan buku pedoman PKL dan penulisan laporan tugas akhir.
\end{abstract}

Kata kunci: Praktik Kerja Lapangan (PKL), Permasalahan PKL, Mahasiswa D-3

\section{PENDAHULUAN}

Kualitas pendidikan dan lulusannya perlu ditingkatkan melalui pengembangan program dan kurikulum. Salah satu yang merupakan program dalam kurikulum adalah Praktik Kerja Lapangan, yang merupakan media untuk pembelajaran dan pelatihan secara nyata di dunia kerja bagi para mahasiswa sebelum mereka menyelesaikan studinya di Politeknik
Negeri Jakarta. Sebelum mengakhiri masa studinya, mahasiswa diwajibkan melaksanakan latihan kerja dalam rangka penerapan ilmu pengetahuan yaitu dalam bentuk Praktik Kerja Lapangan (PKL). Praktik Kerja Lapangan dilaksanakan di perusahaan swasta, perusahaan BUMN atau di Instansi Pemerintah.

Beberapa aturan yang harus diikuti oleh mahasiswa yang dimulai dengan tahapan mengikuti praktik kerja lapangan, 
prosedur pengajuan proposal dan prosedur pelaksanaan praktik kerja lapangan. Mahasiswa harus menentukan bidang apa yang diminatinya dan berkonsultasi dengan ketua program studi. Dalam pelaksanaannya mahasiswa mengalami permasalahan dan keluhan dari mulai permasalahan pengajuan proposal PKL, permasalahan pada saat pelaksanaan PKL dan permasalahan setelah selesai PKL selanjutnya proses penyusunan laporan tugas akhir.

Dari semua permasalahan yang ditemukan tersebut kemudian penulis menganalisis dan mencoba mengevaluasi agar diperoleh pemecahannya dan solusi untuk nantinya dapat dilakukan perbaikan dan penyempurnaan.

\section{Rumusan Masalah}

Berlatar belakang hal di atas, penelitian ini akan menggali kesadaran bela negara pada mahasiswa terhadap unsur bela negara, yaitu cinta tanah air, kesadaran berbangsa dan bernegara, yakin akan kesaktian Pancasila, rela berkorban untuk bangsa dan negara, dan memiliki kemampuan awal bela negara. Permasalahan dalam penelitian berjudul Kesadaran Bela Negara pada Mahasiswa ialah:

1. Bagaimana wujud cinta tanah air pada mahasiswa?

2. Bagaimana kesadaran berbangsa dan bernegara pada mahasiswa?

3. Bagaimana tingkat keyakinan kesaktian Pancasila pada mahasiswa?

4. Bagaimana kerelaan berkorban untuk bangsa dan negara pada mahasiswa?

5. Bagaimana kemampuan awal bela negara pada mahasiswa?

\section{Tinjauan Pustaka}

Rumusan permasalahan dalam penelitian ini yaitu:

1. Permasalahan pada saat pengajuan praktik kerja lapangan.

2. Permasalahan dalam pelaksanaan praktik kerja lapangan.
3. Permasalahan setelah pelaksanaan praktik kerja lapangan (Penyusunan Laporan).

\section{Tinjauan Pustaka}

Menurut Wilson Bangun dalam bukunya Manajemen Sumber Daya Manusia (207: 2012): "Praktik Kerja Lapangan adalah cara lain yang sering digunakan pada pelatihan internal yang diselenggarakan oleh perusahaan. Praktik Kerja Lapangan merupakan suatu kegiatan yang paling sering digunakan karena sifatnya yang fleksibel dan relevan dengan pekerjaan karyawan”.

Menurut Ardana dkk, dalam bukunya Manajemen Sumber Daya Manusia (98: 2012): "Sistem Magang dengan bentuk coaching melalui seorang pemimpin mengajarkan cara-cara kerja yang benar kepada bawahannya di tempat pekerjaannya”.

Mengacu pada kedua metode pelatihan yang dikemukakan di atas sangat relevan diterapkan untuk para mahasiswa semester akhir sebagai persiapan yang nantinya setelah lulus akan terjun ke dunia kerja. Selama melaksanakan praktik di perusahaan, mahasiswa bisa belajar banyak dari suvervisor atau pimpinan, dan juga belajar dari para karyawan. Di samping itu dengan bekal ilmu pengetahuan dan keterampilan yang sudah diperoleh di bangku kuliah, mahasiswa dapat mengaplikasikannya dengan praktik langsung di perusahaan dalam menyelesaikan tugas-tugas pekerjaan kantor.

Di dalam Buku Pedoman Praktik Kerja Lapangan dan Penulisan Laporan Tugas Akhir disebutkan bahwa Praktik Kerja Lapangan (PKL) adalah kegiatan mahasiswa dalam rangka penerapan ilmu pengetahuan di perusahaan atau instansi pemerintah, selama lebih kurang tiga bulan. Setelah selesai melaksanakan PKL, mahasiswa diwajibkan membuat laporan PKL dalam bentuk Laporan Tugas Akhir. Laporan Tugas Akhir adalah karya ilmiah mahasiswa pada akhir 
masa pendidikan dalam bentuk hasil praktik kerja lapangan yang ditulis dalam bentuk laporan dan dapat dipertangung jawabkan secara akademik.

\section{HASIL DAN PEMBAHASAN}

Berdasaran hasil rangkuman mengenai tempat dilaksanakannya pkl, diperoleh data lebih banyak di perusahaan swasta yaitu sebanyak 43 perusahaan swasta, yang lainnya sebanyak 32 instansi pemerintah dan BUMN sebagai tempat mahasiswa pkl. Beberapa dari perusahaan swasta, BUMN dan Instansi pemerintah tersebut sejak beberapa tahun memang sudah menjadi langganan tetap untuk mahasiswa melaksanakan pkl. Tempattempat tersebut akhirnya menjadi referensi bagi mahasiswa angkatan berikutnya untuk menjadikannya tempat pkl. Namun banyak juga mahasiswa harus mencari sendiri tempat pkl. Hal ini menjadi kendala dalam hal waktu dan jarak, juga informasi tentang perusahaan dimana beberapa mahasiswa mengeluh kesulitan mencari tempat pkl.

Berdasarkan hasil rangkuman mengenai bidang peminatan, diperoleh data bidang peminatan yang dipilih ada 12 bidang yaitu: bidang Administrasi (39), MSDM (24), Kesekretariatan (10), Marketing (10), PR (6), Keuangan (5), Kearsipan (3), K3 (3), selanjutnya Pelayanan Prima, sales, Pajak, HRD masing-masing sebanyak 2. Berikut diperlihatkan dalam gambar:

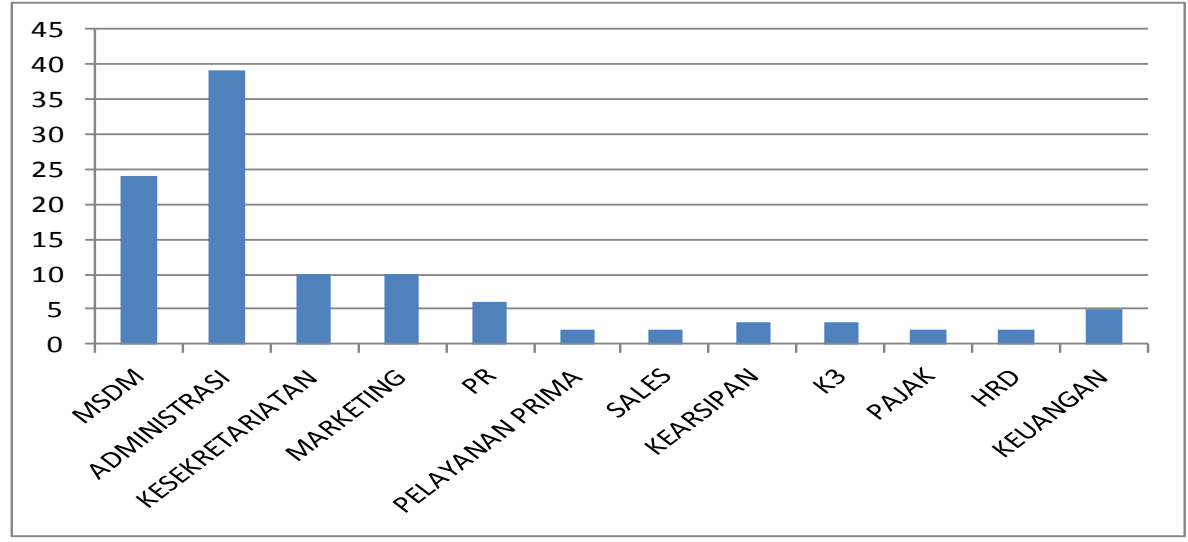

Gambar 1. Bidang Peminatan

Dari gambar di atas terlihat bidang yang paling banyak diminati adalah bidang administrasi yang mendominasi kemudian bidang MSDM. Menurut analisis penulis ke depannya masih banyak bidang-bidang lainnya yang bisa dipilih yang terkait dengan materi yang terdapat pada suatu mata kuliah. Mahasiswa masih terfokus pada beberapa bidang saja, dikarenakan kurangnya informasi mengenai bidang yang lainnya.

Permasalahan yang dialami mahasiswa berkaitan dengan pelaksanaan praktik kerja lapangan. a. Permasalahan pada saat pengajuan proposal PKL

- Kurang sosialisai dan pembekalan tentang PKL.

- Kurangnya informasi tentang jumlah quota bidang peminatan.

- Kesulitan menentukan bidang peminatan.

- Kendala dalam administrasi seperti pengurusan surat pengantar.

- Lambatnya pelayanan dari bagian administrasi.

- Kesulitan dalam mencari tempat PKL

- Kurang informasi tentang perusahaan/Instansi tempat PKL 
b. Permasalahan pada saat pelaksanaan PKL

- Ketidaksesuaian antara bidang peminatan yang dipilih dengan data yang tersedia di tempat PKL

- Pekerjaan yang diberikan tidak sesuai dengan yang diharapkan.

- Terlalu banyak form penilaian yang harus diisi.

- Beberapa mahasiswa menginginkan jangka waktu PKL diperpanjang, hal ini diminta juga oleh pihak perusahaan, karena projeknya masih berjalan.

c. Permasalahan setelah pelaksanaan PKL( penulisan laporan)
- Beberapa mahasiswa kesulitan memahami buku pedoman penulisan tugas akhir.

- Kendala komunikasi antara mahasiswa dengan dosen pembimbing.

- Beberapa mahasiswa mengalami kesulitan pada saat bimbingan, disebabkan adanya perbedaan aturan penulisan TA dari pembimbing dengan aturan di buku pedoman.

Hasil pengisian kuesioner penelitian untuk mahasiswa PKL Prodi AB-Jurusan AN, jumlah mahasiswa peserta pkl semua 108 orang, sebanyak 67 orang mengisi kuesioner tersebut. Berikut dalam bentuk gambar dan keterangannya:



Gambar 2. Permasalahan pada saat pengajuan proposal PKL

Dari gambar di atas terlihat jawaban responden berimbang dari setiap butir pertanyaan menyatakan lebih banyak menjawab sangat setuju dan setuju.

Keterangan gambar:

PADA SAAT

PENGAJUAN PROPOSAL PKL

a) Jurusan sebaiknya menginformasikan jumlah quota setiap bidang peminatan,

b) Perlu diperbanyak pilihan bidang peminatan supaya tidak menumpuk di salah satu bidang favorit saja,

c) Jurusan punya database perusahaan dan Instansi yang sudah bekerjasama, dan menerima Mahasiswa untuk PKL, d) Perlu sosialisasi kepada mahasiswa mengenai situasi, kondisi dan lingkungan kerja di perusahaan,

e) Dalam hal mengurus surat pengantar supaya tidak dibatasi dan bisa lebih dipermudah,

f) Format surat pengantar sebaiknya diperbarui dan sudah disetujui penggunaannya oleh para structural,

g) Petugas administrasi sebaiknya lebih teliti dalam penanganan dan penyimpanan surat, agar tidak terjadi kehilangan,

h) Pelayanan petugas administrasi lebih ditingkatkan, agar lebih baik dan lebih cepat 


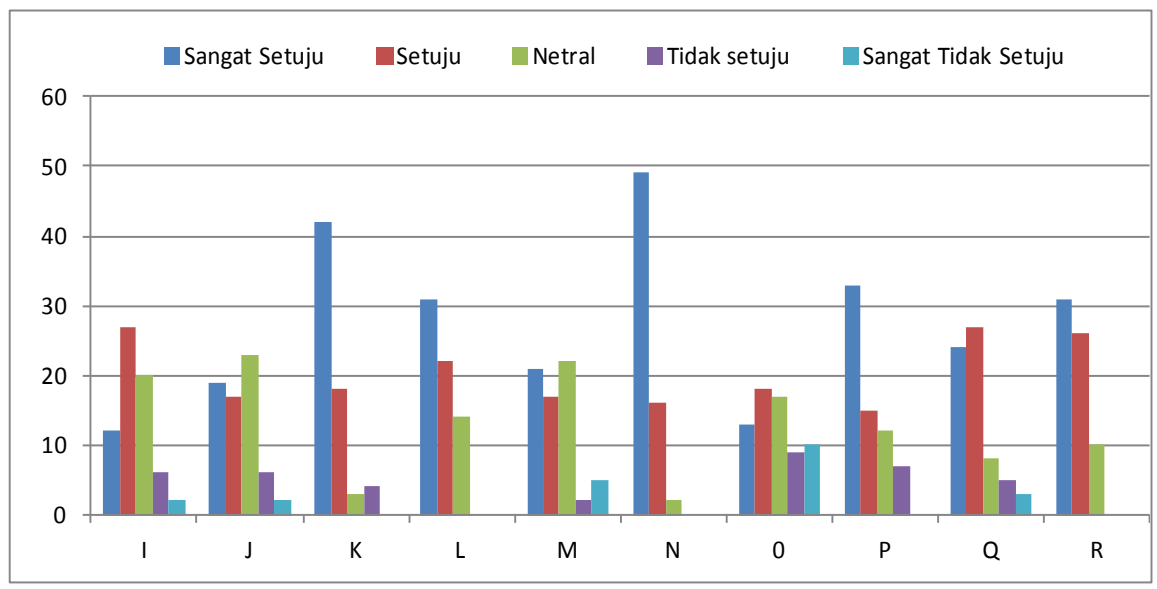

Gambar 3. Permasalahan pada saat pelaksanaan PKL

Dari gambar di atas terlihat jawaban responden hampir merata di setiap butir pertanyaan, dimana jawaban sangat setuju didominasi pada butir pertanyaan $\mathrm{N}$, yaitu aplikasi pada mata kuliah (Excel, Access dll) diperbanyak dan diperdalam diberikan agar Mahasiswa lebih terampil. Berikutnya jawaban sangat setuju juga banyak pada butir pertanyaan $\mathrm{K}$, yaitu lembar penilaian untuk mahasiswa dibuat simple dan tidak terlalu banyak. Sedangkan untuk butir pertanyaan L, P dan $\mathrm{R}$ jawabannya berimbang.

Keterangan gambar:

\section{PADA SAAT PELAKSANAAN PKL}

a) Masih adanya ketidaksesuaian pekerjaan yang diberikan saat PKL dengan apa yang diajarkan di kampus

b) Masih adanya ketidaksesuaian antara bidang peminatan yang dipilih dengan data yang ada di tempat PKL

c) Lembar penilaian untuk mahasiswa dibuat simple dan tidak terlalu banyak d) Laporan mingguan sebaiknya diganti dengan laporan per project/pekerjaan selesai agar lebih efektif. Karena menyelesaikan satu project membutuhkan waktu lebih dari 1 minggu

e) Kurang detailnya lembar absen, perlu ditambahkan jam masuk dan jam keluar kantor

f) Aplikasi pada mata kuliah (Excel, Access dll) diperbanyak dan diperdalam diberikan agar Mahasiswa lebih terampil

g) Terdapat kendala komunikasi dan sulitnya bertemu dengan dosen pembimbing

h) Perlu disosialisasikan untuk proses bimbingan bisa melalui email

i) Waktu pelaksanaan PKL perlu diperpanjang hingga 6 bulan (satu semester)

j) Perlunya monitoring dan evaluasi dari jurusan, pada saat PKL berjalan dan terjadwal. 


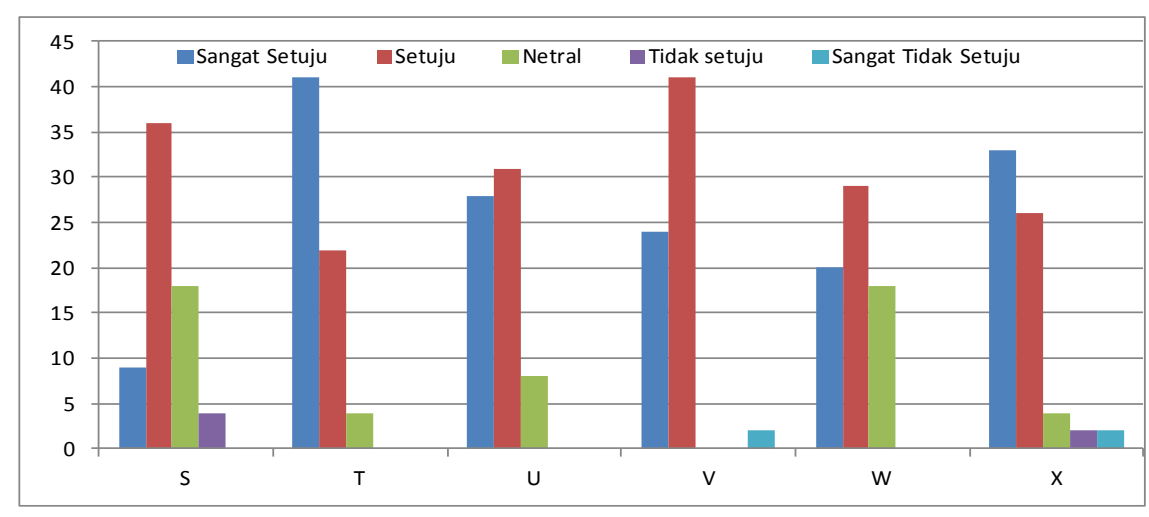

Gambar 4. Permasalahan setelah PKL (penulisan laporan)

Dari gambar di atas terlihat jawaban setuju berimbang untuk setiap butir pertanyaan, dan didominasi sangat setuju pada pertanyaan butir $\mathrm{T}$, yaitu perlu penyempurnaan Buku Pedoman Penulisan TA dan komitmen dosen pembimbing untuk mengikuti aturan dalam buku pedoman tersebut. Berikutnya setuju pada butir pertanyaan $\mathrm{V}$, yaitu Jurusan perlu mengevaluasi dan memperbaiki pengaturan dalam penjadwalan sidang dan aturan pengumpulan hard cover.

Keterangan gambar:

SETELAH

PKL(PENULISAN LAPORAN)

a) Mahasiswa kesulitan memahami Buku Pedoman Penulisan TA

b) Perlu penyempurnaan Buku Pedoman Penulisan TA dan komitmen dosen pembimbing untuk mengikuti aturan dalam buku pedoman tersebut

c) Jika terjadi perubahan dosen pembimbing agar diinformasikan ke dosen pembimbing sebelumnya

d) Jurusan perlu mengevaluasi dan memperbaiki pengaturan dalam penjadwalan sidang dan aturan pengumpulan hard cover

e) Pihak Jurusan sebaiknya memiliki MOU/MOA dengan perusahaan di mana Mahasiswa PKL

f) Jurusan perlu memiliki sistem informasi pengurusan PKL yang terencana dan memudahkan untuk diterapkan.
Hasil rangkuman komentar dan masukan dari perusahaan diperoleh banyak masukan dari pihak perusahaan agar mahasiswa bisa meningkatkan kemampuannya sesuai dengan bidang pekerjaan yang ada di tempat pkl. Tetapi banyak juga masukan untuk hal-hal umum yang berkaitan dengan penguasaan soft skillnya.

Berikut ini rangkuman beberapa masukan dari perusahaan antara lain:

1. Agar lebih ditingkatkan penguasaan MS. Office dan MS. Excel.

2. Meningkatkan penguasaan bahasa asing secara lisan maupun tulisan dalam kontes bisnis.

3. Menguasai korespodensi.

4. Menguasai keterampilan softskill, kecakapan bersosialisasi dengan rekan kerja.

5. Mengetahui sistem pengarsipan terbaru, peralatan dan perlengkapan arsip terkini.

6. Lebih teliti dan kecepatan dalam bekerja dan problem solving.

7. Meningkatkan kemampuan dalam public speaking.

\section{KESIMPULAN DAN SARAN}

Dari hasil penelitian ini ditemukan dan diperoleh banyak permasalahan yang dialami oleh mahasiswa dalam mengikuti praktik kerja lapangan. Permasalahan dialami pada saat mulai pengajuan proposal PKL, kemudian permasalahan pada saat pelaksanaan PKL, dan 
permasalahan setelah selesai PKL yang dilanjutkan dengan pembuatan laporan PKL dalam bentuk laporan tugas akhir. Berdasarkan hasil pengisian kuesioner dimana butir-butir peryataannya adalah bersifat positif yang tujuannya mengarahkan, dihasilkan jawaban dari responden yang berimbang dan didominasi oleh jawaban sangat setuju dan setuju. Hal ini berarti dapat disimpulkan bahwa mahasiswa menginginkan adanya perbaikan dan penyempurnaan pada pelaksanaan praktik kerja lapangan dengan perencanaan yang lebih baik, terorganisir dan sistematis, sehingga memudahkan bagi mereka dalam melaksanakan praktik kerja lapangan.

Sebagai tempat pelaksanaan PKL, mahasiswa mendapatkan referensi dari angkatan sebelumnya tentang perusahaanperusahaan yang sebelumnya sudah sering menjadi tempat PKL. Namun banyak juga mahasiswa harus mencari sendiri tempat pkl. Hal ini menjadi kendala dalam hal waktu dan jarak, juga informasi tentang perusahaan dimana beberapa mahasiswa mengeluh kesulitan mencari tempat PKL.

Pemilihan bidang peminatan masih terfokus hanya pada beberapa bidang saja yang favorit menjadi pilihan. Bidang yang paling banyak diminati adalah bidang administrasi yang mendominasi kemudian berikutnya bidang MSDM. Bidang lainnya masih kurang diminati, padahal masih banyak bidang-bidang lainnya yang bisa dipilih yang terkait dengan materi yang terdapat pada suatu mata kuliah. Kurangnya informasi dan sosialisasi pada bidang-bidang lainnya yang menyebabkan mahasiswa kesulitan menentukan bidang peminatan.

Perusahaan tempat mahasiswa melaksanakan PKL, menginginkan agar mahasiswa meningkatkan pengetahuan dan kemampuannya sesuai dengan bidang pekerjaan yang ada di tempat PKL. Selain itu sangat diharapkan meningkatkan penguasaan kemampuan dalam hal-hal seperti; penguasaan MS. Office dan MS. Excel, meningkatkan penguasaan bahasa asing secara lisan maupun tulisan dalam kontes bisnis, menguasai korespodensi, menguasai keterampilan softskill, kecakapan bersosialisasi dengan rekan kerja, mengetahui sistem pengarsipan terbaru, peralatan dan perlengkapan arsip terkini, lebih teliti dan kecepatan dalam bekerja dan problem solving, meningkatkan kemampuan dalam public speaking.

Berdasarkan analisis permasalahan yang dialami oleh mahasiswa dan masukan dari dosen pembimbing dan struktural, maka penulis menyarankan Jurusan perlu membuat database daftar perusahaan-perusahaan dan instansi yang sudah pernah menjadi tempat PKL, dan juga menjajagi kemungkinan untuk dibuatkan kerjasama dalam bentuk MOU. Sehingga memudahkan bagi mahasiswa mencari tempat PKL.

Segera melakukan revisi dan penyempurnaan terhadap buku pedoman pelaksanaan PKL dan buku pedoman penulisan laporan tugas akhir. Hal ini sudah dilakukan oleh prodi AB pada saat diadakan Workshop, namun masih dalam proses editing dan penyelesaian.

Dari pembahasan hasil penelitian dan analisis sebelumnya penulis menyarankan sebuah konsep rancangan aplikasi sistem informasi praktik kerja lapangan yang terintegrasi dengan layanan internet dan web, yang diharapkan dengan konsep tersebut nantinya dapat dibuatkan aplikasinya dan dapat diterapkan. Konsep rancangan aplikasi sistem informasi PKL tersebut bertujuan memudahkan semua pihak yang berkaitan dengan pelaksanan PKL; baik mahasiswa, dosen, perusahaan dan tentunya Jurusan Administrasi Niaga, khususnya Program Studi Administrasi Bisnis. 


\section{DAFTAR PUSTAKA}

Ardana dkk. 2012. Manajemen Sumber Daya Manusia. Yogyakarta: Graha Ilmu.

Bangun Wilson. 2012. Manajemen Sumber Daya Manusia. Jakarta: Penerbit Erlangga

Buku Pedoman Praktik Kerja Lapangan Jurusan Administrasi Niaga Program Studi D3 Administrasi Bisnis. 2016.

Buku Laporan PKL mahasiswa Administrasi Bisnis tahun 2017/2018.

Sugiyono. 2007. Metode Penelitian Administrasi Dilengkapi dengan Metode R \& D. Bandung: CV ALFABETA.

Jurnal:

Ayu Adininggar, Ali Wafa. 2016. Analisis Permasalahan Pelaksanaan Praktik Kerja Lapangan

Universitas Negeri Malang. Jurnal JPE. Volume 9. Nomor 1.

Muhammad Arifin. 2014. Analisa dan Perancangan Sistem Informasi Praktik Kerja Lapangan pada Instansi/Perusahaan. Jurnal Simetris: Vol. 5 No. 1 April 2014. Issn: 22524983. 